\title{
Effects of Water Replenishment from Yellow Riv- er on Water Quality of Hengshui Lake 1 Wetland
}

\author{
Xu Weigang ${ }^{1,2}$, Yu Yilei ${ }^{1,2}$, Ma Muyuan ${ }^{1,2, *}$, Guo Jia ${ }^{1,2}$, Zhao Nana $^{1,2}$, Li Xiaoxiaa ${ }^{1,2}$ \\ ${ }^{1}$ Institute of Wetland Research, Chinese Academy of Forestry, Beijing 100091, China \\ ${ }^{2}$ Beijing Key Laboratory of Wetland Services and Restoration, Beijing 100091, China
}

*Corresponding author: Ma Muyuan, Institute of Wetland Research, Chinese Academy of Forestry, Beijing 100091, China, E-mail: xiaogu67@sina.com

\begin{abstract}
:
Hengshui Lake Wetland is the only national wetland and bird nature reserve in the North China Plain. It plays an important role in maintaining the species diversity and ecological balance. In recent years, due to industrial and agricultural production, infrastructure and ecological environment construction and other reasons, the infiltration, runoff, evapotranspiration and other water balance elements was changed, which reduced runoff into the lake. In order to ease the tense water resources situation in the region, Hengshui Lake is replenished each year by Yellow River water. Although Diversion Yellow River Wetland has made direct water supply protection, but also affected the ecology and environment of Hengshui Lake wetlands. In order to understand how artificial water diversion can affect the ecological environment of natural lakes, this paper analyzes the effects of artificial water storage on the water quality of the lake by using the measured data of water samples in the lake. The results showed that the water level of Hengshui Lake showed an upward trend after the diversion from the Yellow River. Comprehensive pollution index showed a downward trend, but Hengshui Lake wetlands are still slightly polluted. Diversion of Yellow River diversion into the lake of the ecological health of Hengshui also caused some impact.
\end{abstract}

\section{Introduction}

Wetland is one of the most widely distributed and productive natural ecological environment types in the world ${ }^{[1]}$. Wetland has conserved water source, purify water quality, control flood, regulating climate, control soil erosion and reduce environmental pollution. It can also provide a wide range of products to humans and leisure places, has great economic value and social value. Healthy wetland ecosystem is an important part of ecological security and an important foundation for sustainable economic and social development.

Over the past 150 years, due to changes in the natural environment and the impact of human activities, more than $50 \%$ of the world's wetlands have been degraded or lost ${ }^{[2]}$. About 26 percent of wetlands are used for agricultural production ${ }^{[3]}$. In the UK, about 23 percent of estuarine wetlands and 40 percent of meadow wetlands are destroyed. In southern Africa, 58 percent of natural wetlands in the Mfolozi valley and 90 percent of wetlands in the Tugela basin have disappeared ${ }^{[4]}$. In South East Asia, most wetlands have been reclaimed for residential and agricultural land. 78 percent of natural swamp wetlands in Sanjiang plain, China's largest freshwater swamp wetland, are gradually disappearing in recent 50 years. The loss and degradation of wetlands has weakened the wetland ecological service function $^{[5]}$.

Hydrological conditions are the characteristics of the wetland degradation factors. It is also the driving factor of other feature factors such as wetland biology and soil ${ }^{[6]}$. Therefore, it is essential to improve and restore the hydrological conditions during the restoration of wetland conservation and ecological functions.

Ecological water replenishment is typical measures for the restoration of wetland environment. China started to water replenish from the Nenjiang River to Zhalong wetland in 2001.

The water replenishment objects are the flood marsh wetland, estuarine wetland and lake wetland, which are caused by natural environment or human activities that cause water shortage. Water replenishment from Yellow River has direct and indirect influence on the ecology and environment of Hengshui lake wetland.

\section{Received date: November 06, 2017 \\ Accepted Date: February 23, 2018 \\ Published Date: February 28, 2018}

Citation: Muyuan, M. Effects of Water Replenishment from Yellow River on Water Quality of Hengshui Lake 1 Wetland. (2018) J Marine Biol Aquacult 4(1): 11- 13.

Copy Rights: (C) 2018 Muyuan, M. This is an Open access article distributed under the terms of Creative Commons Attribution 4.0 International License. 
For understand the effect of water replenishment on the ecological environment of natural lakes, this paper combines historical survey data and measured data, (1) provide data support to prevent the degradation and extinction of Hengshui Lake by analyzing the relationship between the transferable water quantity and the wetland area. (2) Discussed the management of water quality in Hengshui lake by analyzing the relationship between transferable water quantity and wetland water quality.

\section{Study area 55}

Hengshui lake is located in Hengshui City, Hebei Province. The range is $115^{\circ} 27^{\prime} 50^{\prime \prime} \sim 115^{\circ} 41^{\prime} 55^{\prime \prime}, 37^{\circ} 31^{\prime} 40^{\prime \prime} \sim 37^{\circ} 41^{\prime} 56^{\prime \prime}$. The maximum width of east-west direction is $22.28 \mathrm{~km}$. The maximum length is $18.81 \mathrm{~km}$ from the north to the south. The total area of Hengshui Lake is $187.87 \mathrm{~km}^{2}$. The Hengshui Lake wetland is an important base for the protection of birds in China, is also place for scientific research, biodiversity conservation, environmental pollution monitoring. It is the only preserved inland freshwater wetland ecosystem in the North China Plain.

Natural rainfall and passenger water are the main source of surface water in Hengshui Lake. The climate is very dry. The Hengshui Lake annual rainfall is only one quarter of the annual evaporation. Therefore the water source of Hengshui Lake mainly relies on artificial water supply. The main water source of artificial water diversion is the Yellow River water: The use of Wei Qianqu transport the Yellow River water, and then enter the Hengshui Lake through the Wangkou gate. This water transfer line is part of the South-North Water Diversion Project.

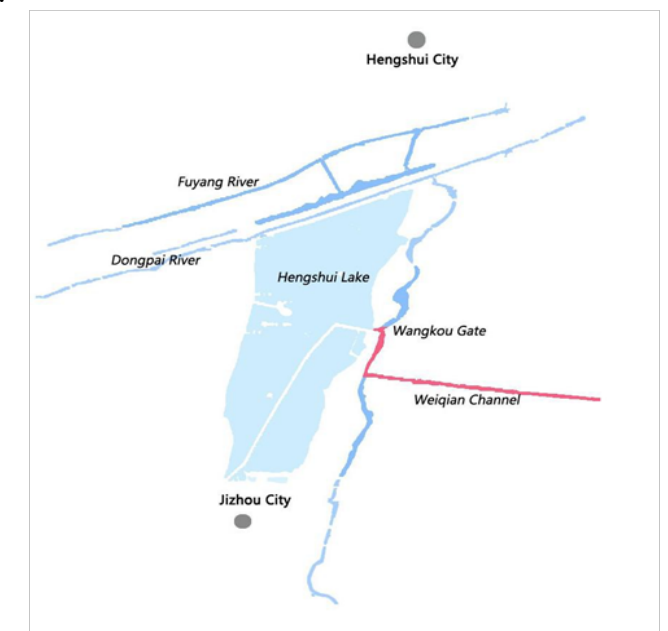

Figure 1: The location of study area

\section{Methods}

The sampling sites were located in Wangkou gate, central lake, and Dazhao gate. Dazhao gate is the lake water-break gate. Samples were collected from each point in triplicate. The water samples were collected in 500-mL plastic bottles and stored at $4^{\circ} \mathrm{Cuntil}$ analysis. A portable water quality probe (YSI 6820) was used to measure DO, temperature, and $\mathrm{pH}$. Water quality index Ammonia nitrogen and Phosphorus concentration determination were measured using Nessler reagent colorimetric method and molybdenum antimony anti-spectrophotometry. Water quality data before 2014 comes from Hengshui water environment monitoring center of Hebei Province. Using the com- prehensive pollution index $\mathrm{P} n$ analysis before and after the water transfer Hengshui Lake water quality situation:

$$
P_{n}=\frac{1}{n} \sum_{i=1}^{n} \frac{C_{i}}{C_{s i}}
$$

$\mathrm{P} n$ is the comprehensive pollution index; $\mathrm{n}$ is the number of pollutants; $C i$ is the measured concentration of the i pollutants; $C s i$ is the evaluation standard value of the i pollutants.

\section{Results and Discussion}

The water flow into the Hengshui Lake mainly includes precipitation and the inflow of five rivers. Hengshui Lake outflow of water in addition to evaporation and leakage, but also includes industrial water consumption, lake water consumption around the lake. Hengfeng power plant used water million $\mathrm{m}^{3}$ from Hengshui Lake every year in 1995-2004. Hengfeng power plant after the second phase of the project, the annual water intake of 170 million $\mathrm{m}^{3}$. Hengshui Lake Basin annual production of drain was 33.76 million $\mathrm{m}^{3}$ before 1994. However, Annual production of drain water was 23.40 million $\mathrm{m}^{3}$ after 1994, which reduced by more than $30 \%$. The decrease of water production and the increase of water consumption are one of the main causes of the deterioration of ecological environment in Hengshui Lake. The first Yellow River diversion in 1994. A total of diversion of yellow water into the lake water volume of 106.28 million $\mathrm{m}^{3}$.

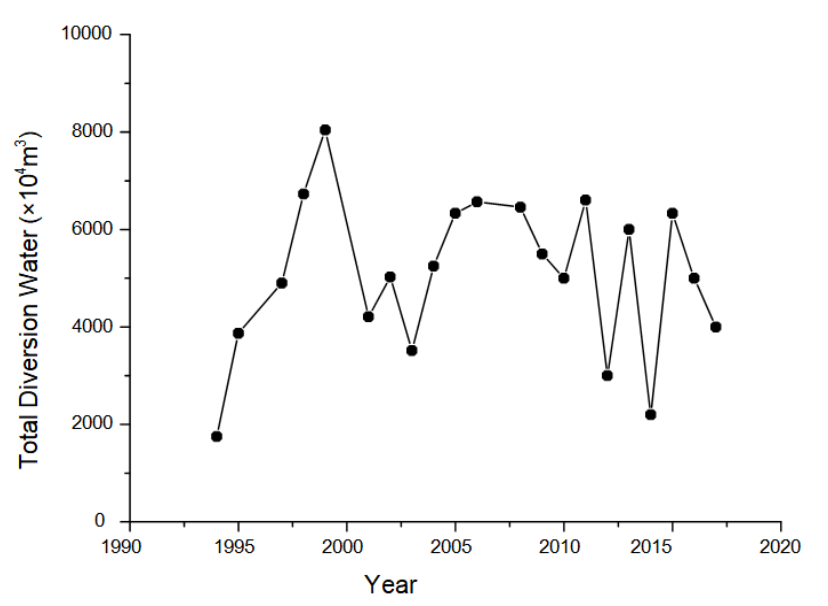

Figure 2: Total diversion water from 1994 to 2016

After the Yellow River Diversion, the average annual water level of Hengshui Lake increased from $18.39 \mathrm{~m}$ before $1975-1993$ to $19.74 \mathrm{~m}$, increasing by $7.34 \%$. The maximum water level was above $20 \mathrm{~m}$, and the guarantee rate was increased from $36.84 \%$ to $86.67 \%$ before the Yellow lead. The highest average water level of Hengshui lake water diversion before $19.55 \mathrm{~m}$, after the water diversion of Hengshui lake water level reached the highest average $20.86 \mathrm{~m}$ in 2017 . The average maximum water diversion project implementation of Hengshui Lake years increased by $1.02 \mathrm{~m}$. Before the Yellow River Diversion, the frequency of drying up was $68.42 \%$, and there was no drying up after diverting water from the Yellow river. The maximum annual variation of water level before Yellow River diversion is $2.69 \mathrm{~m}$, and charge to $2.00 \mathrm{~m}$. 


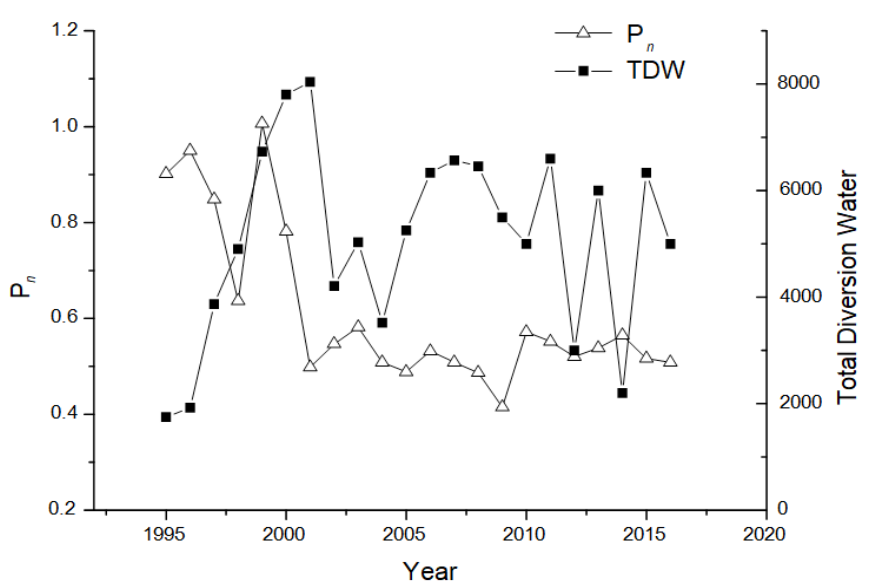

Figure 3: Comparison of annual water quality changes

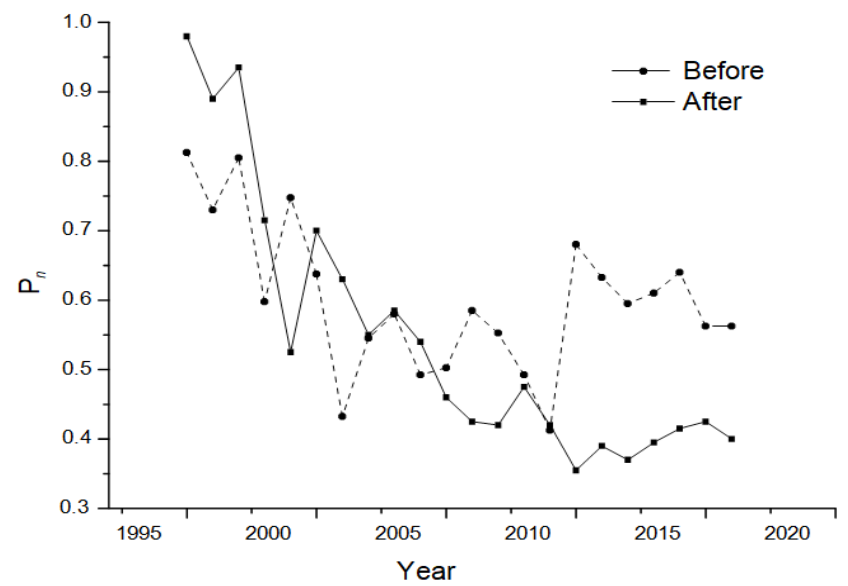

Figure 4: Comparison of water quality changes before and after water transfer

It can be seen from the figure, there was not much difference between the water quality before and after water diversion before 2000, and the impact of water diversion on water quality was relatively small. After 2000, the gap between the water quality before and after water diversion is gradually revealed, and the role of water diversion is also highlighted. Especially after 2010 , the water quality before water diversion Pn is about 0.5 , and the water quality Pn after water diversion will be reduced to about 0.4 . It shows that the pollution of Hengshui Lake has been basically stable in recent years. Appropriate water diversion can obviously reduce water pollution.

\section{Conclusion}

1. Water diversion in time from the Yellow River can replenish the amount of water coming into the lake in Hengshui Lake. Frequent dry-up in the lake area has been alleviated. However, the restore ecological environment of Hengshui Lake still needs to be further studied and determined. Hengshui Lake wetland water supply protection measures still need to be studied.

2. The comprehensive pollution index of Hengshui Lake has a decreasing trend since the Yellow River. However, when the Yellow River water is introduced, the Rushes and other pollutants in the Yellow River basin will be introduced into Hengshui Lake with the river water. The related governance measures need further study.

3. The amount of sand in the lake has a certain impact on the ecological health of Hengshui Lake. The Yellow River is the river with the largest amount of sediment in our country. Although sediment has been settled before the Yellow River enters Hengshui Lake, some sediment is still introduced into Hengshui Lake. This problem should also be taken seriously.

Acknowledgement: This study was supported by the Fundamental Research Funds for the Central Non-profit Research Institution of CAF (No: CAFINT2014C15).

\section{References}

1. Piva, M.L., Boyd, R., Boyd, J., et al. Evaluating Wetland Vegetation Establishment at the Baker Wetlands, Douglas County, Kansas. (2016) Transactions of the Kansas Academy of Science 119(1): 49-63.

PubMed | CrossRef |Others

2. Beebe, D.A., Castle, J. W., Molz, F.J., et al. Effects of evapotranspiration on treatment performance in constructed wetlands: Experimental studies and modeling. (2014) Ecological Engineering 71: 394-400.

PubMed | CrossRef | Others

3. Moser, M., Prentice, R.C., Vessem J.V. Waterfowl and wetland conservation in the 1990s. (1993) 149.

PubMed | CrossRef |Others

4. Taylor, A.R.D., Howard, G.W., Begg, G. W. Developing wetland inventories in southern Africa: A review. (1995) Vegetation 118(1-2): 57-79.

PubMed $\mid$ CrossRef $\mid$ Others

5. Wang, H., Ge, Z., Yuan, L., et al., Evaluation of the combined threat from sea-level rise and sedimentation reduction to the coastal wetlands in the Yangtze Estuary, China. (2014) Ecological Engineering 71: 346-354.

PubMed | CrossRef | Others

6. Qin, L., Jiang, M., Tian, W., et al., Effects of wetland vegetation on soil microbial composition: A case study in Tumen River Basin, Northeast China. (2017) Chinese Geographical Science 27(2): 239-247.

PubMed | CrossRef | Others

Submit your manuscript to Ommega Publishers and we will help you at every step:

- We accept pre-submission inquiries

- Our selector tool helps you to find the most relevant journal

- We provide round the clock customer support

- Convenient online submission

- Thorough peer review

- Inclusion in all major indexing services

- Maximum visibility for your research

Submit your manuscript at

OMMEgA Publishers

https://www.ommegaonline.org/submit-manuscript 